\title{
KADAR INTERLEUKIN-4 DAN INTERLEUKIN-8 FESES NEONATUS PREMATUR YANG MENDAPAT ASI, PREDOMINAN ASI, PREDOMINAN SUSU FORMULA, DAN SUSU FORMULA
}

\author{
Choirul Anam ${ }^{\star \bowtie}$, Eko Sulistijono**, HMS Chandra Kusuma**
}

\begin{abstract}
Abstrak
Bayi prematur apabila usia gestasi kurang dari 37 minggu saat lahir. Strategi yang telah terbukti untuk mengurangi kejadian risiko infeksi,dan gangguan saluran pencernaan pada bayi prematur adalah konsumsi air susu ibu (ASI). Saluran cerna dipengaruhi proses regulasi sitokin proinflamasi dan antiflamasi. Hasil penelitian menunjukkan interleukin-4 dan interleukin-8 berperan pada kondisi inflamasi saluran cerna. Penelitian ini untuk membuktikan adanya perbedaan kadar interleukin 4 (IL-4) dan interleukin 8 (IL-8) pada feses neonatus prematur yang mendapatkan ASI, predominan ASI, predominan susu formula, dan susu formula (SF), serta membandingkan kadar IL-4 dan IL-8 feses yang menggunakan ASI dibandingkan predominan ASI, predominan SF, dan SF. Penelitian ini menggunakan desain cross sectional. Populasi penelitian adalah bayi prematur yang dirawat di ruang Neonatologi RS. Dr. Saiful Anwar Malang selama periode Maret-April 2018, dengan jumlah sampel 24 pasien. Hasil analisis statistik mendapatkan perbedaan yang signifikan kadar IL-4 feses $(p=0,007)$ dan IL-8 feses $(p=0,014)$ pada keempat kelompok nutrisi dengan nilai $p<0,05$. Kadar IL-4 dan IL-8 feses kelompok ASI dibandingkan predominan SF dan SF didapatkan nilai $p<0,05$. Dapat disimpulkan bahwa ada perbedaan kadar IL-4 dan kadar IL-8 feses antara kelompok bayi prematur yang mendapatkan ASI, predominan ASI, predominan SF, dan SF. Kadar IL-4 feses kelompok ASI lebih tinggi dibandingkan kelompok predominan SF dan kelompok SF, dan kadar interleukin-8 feses kelompok ASI lebih rendah dibandingkan kelompok predominan SF dan SF.
\end{abstract}

Kata kunci: ASI, interleukin 4, interleukin 8, prematur, susu formula.

\section{LEVEL OF FECAL INTERLEUKIN-4 AND INTERLEUKIN-8 OF PREMATURE NEONATES RECEIVING BREAST MILK, PREDOMINANTLY BREAST MILK, PREDOMINANTLY FORMULA, AND FORMULA}

\begin{abstract}
Premature neonates were defined as neonates born at gestational age under 37 weeks. Strategy to decrease the incidence of infection, and gastrointestinal disturbances in premature is consumption of breast milk. Gastrointestinal tract was influenced by the regulation of proinflammatory and antiinflammatory cytokines. A few studies showed that IL-4 and IL-8 had roles in inflammation of gastrointestinal. The aim of this research to identify differences in the level of fecal IL-4 and IL-8 of premature receiving breast milk, predominantly breast milk, predominantly formula, and formula, and also to compare the level of fecal IL-4 and IL-8 receiving breast milk than predominantly breast milk, predominantly formula and formula. This study used a cross-sectional design. Population of this study is premature neonates in the neonatology ward of Dr. Saiful Anwar General Hospital Malang period of March until April 2018 with total sample of 24 patients. It was obtained that there was a significant difference in the level of fecal IL-4 $(p=0.007)$ and IL-8 $(p=0.014)$ of four patient groups, and also the level of fecal IL-4 and IL-8 of breast milk patient compared to predominantly formula and formula resulted in a significant difference $(p<0.05)$. There was a difference in the level of fecal IL-4 and IL-8 of premature neonates receiving of four groups nutrition. Level of fecal IL-4 of breast milk group were higher compared to formula and predominantly formula. Level of fecal IL-8 of breast milk group were lower compared to formula and predominantly formula.
\end{abstract}

Keywords: breast milk, formula, interleukin-4, interleukin-8, premature.

*Program Studi Magister IImu Biomedik, Fakultas Kedokteran, Universitas Brawijaya

**Departemen IImu Kesehatan Anak, Fakultas Kedokteran, Universitas Brawijaya

E-mail: anam_dr86@yahoo.co.id 


\section{Pendahuluan}

Kelahiran bayi prematur didefinisikan sebagai usia gestasi <37 minggu saat lahir, dan menjadi masalah kesehatan global yang terjadi di berbagai negara, baik negara berpenghasilan tinggi maupun berpenghasilan rendah. Insiden kelahiran prematur sekitar $11,1 \%$ yang berarti bahwa 14,9 juta bayi lahir prematur setiap tahun. ${ }^{1}$

Strategi yang telah terbukti untuk mengurangi kejadian risiko infeksi, alergi dan gangguan intake pada bayi prematur adalah penggunaan air susu ibu (ASI). ASI mengandung banyak faktor pertumbuhan dan zat bioaktif lainnya yang tidak ditemukan dalam formula bayi prematur standar, dan faktor-faktor pertumbuhan tersebut berkontribusi terhadap efek pertahanan tubuh. $^{2}$

Salah satu penelitian nutrisi pada bayi prematur di Indonesia menununjukkan proses inflamasi yang lebih rendah dan rendahnya bakteri patogen pada populasi yang menggunakan ASI. Proses inflamasi di saluran cerna dipengaruhi oleh regulasi sitokin, sitokin tersebut mempengaruhi pertahanan epitel serta perlukaan pada saluran cerna. ${ }^{3,4}$

Saluran cerna dipengaruhi proses regulasi sitokin, baik sitokin proinflamasi dan antiflamasi agar terjadi homeostasis. Salah satu sitokin antiiflamasi adalah interleukin-4 (IL-4). Pada kejadian enterokolitis nekrotikan (EKN) kadar IL-4 menunjukkan kadar yang rendah dibandingkan pada kontrol. 3,5

Sebuah penelitian menunjukkan kadar IL-8 feses meningkat pada pasien dengan infeksi saluran pencernaan karena clostridium dengan gejala diare, penelitian lainnya juga menunjukkan peningkatan kadar IL-8 feses pada anak dengan keluhan diare karena rotavirus. Dari hal tersebut menunjukkan IL-8 cukup sensitif menilai kondisi inflamasi saluran cerna $^{6}$ Pemeriksaan IL-4 dan IL-8 feses pada neonatus prematur merupakan pemeriksaan yang menguntungkan karena tidak invasif sehingga mengurangi risiko terjadinya infeksi. Berdasarkan alasan tersebut peneliti ingin membuktikan apakah ada perbedaan kadar IL-4 dan IL-8 feses neonatus prematur yang mendapatkan ASI, predominan ASI, predominan susu formula dan susu formula (SF), serta apakah kadar IL-4 feses pada neonatus prematur yang mendapatkan ASI lebih tinggi dibandingkan predominan ASI, predominan susu formula dan susu formula dan apakah kadar interleukin 8 feses pada neonatus prematur yang mendapatkan ASI lebih rendah dibandingkan predominan ASI, predominan susu formula, dan susu formula.

\section{Bahan dan Metode}

\section{Desain Penelitian}

Penelitian ini menggunakan rancangan studi cross sectional. Penelitian dilakukan di ruang Neonatologi Rumah Sakit Dr. Saiful Anwar (RSSA) Malang dan Laboratorium Fisiologi Fakultas Kedokteran Universitas Brawijaya Malang. Penelitian ini telah disetujui oleh Tim Etik Rumah Sakit Dr. Saiful Anwar Malang dengan nomor surat: 400/177/K.3/302/2017.

\section{Populasi dan Sampel Penelitian}

Populasi penelitian yaitu neonatus prematur yaitu usia gestasi kurang dari 37 minggu yang dirawat pada bulan Maret-April 2018 yang memenuhi kriteria inklusi dan eksklusi, dengan total sampel sebanyak 24 . Sampel kemudian dibagi menjadi kelompok ASI $(n=6)$, Predominan ASI $(n=6)$, Predominan SF $(n=6)$, dan SF $(n=6)$.

Bahan pemeriksaan berasal dari feses yang diambil dengan spatula sebanyak 100 mg. Kemudian dipindahkan ke tabung penampung. Sampel diambil dari feses yang memenuhi persyaratan pengambilan, antara 
lain tabung tempat sampel feses bersih, serta pengiriman dalam waktu kurang dari 30 menit atau disimpan dalam kulkas dengan suhu $-20{ }^{\circ} \mathrm{C}$ dan dikirimkan dengan menggunakan wadah khusus yang dapat menjaga kestabilan suhu. Feses diambil saat bayi mengkonsumsi ASI transisional (usia antara 3 hari sampai 21 hari).

Pemeriksaan Kadar IL-4 dan IL-8 dengan Metode Enzyme-Linked Immunosorbent Assay (ELISA)

Kadar IL-8 dan IL-4 pada sampel feses diukur dengan metode ELISA. Pemeriksaan ELISA menggunakan kit Human IL-8 dan IL4 Immunoassay sesuai dengan instruksi pada produk kit. IL-8 dan IL-4 diukur menggunakan spektrofotometri pada panjang gelombang $450 \mathrm{~nm}$.

\section{Analisis Statistik}

Data dikumpulkan dari hasil pengukuran IL-4 dan IL-8 dari kelompok yang mendapatkan ASI predominan ASI, predominan SF dan yang mendapat SF. Analisis data menggunakan uji normalitas kemudian dilakukan uji komparatif untuk mencari perbedaan pada tiap kelompok dan diolah menggunakan software SPSS-23. ${ }^{8}$

\section{Hasil}

Pada penelitian ini terdapat 7 variabel karakteristik demografi yang diamati yaitu jenis kelamin, masa kehamilan, cara lahir, usia, usia kehamilan, berat badan lahir, panjang badan (Tabel.1). Hasil penelitian mendapatkan median usia 7,5 hari $(6-18$ hari), dengan jumlah laki-laki dan perempuan masing-masing 15 (62\%) dan 9 pasien (38\%). Median usia kehamilan adalah 33 minggu (30-36 minggu), untuk berat badan lahir terendah $1530 \mathrm{~g}$ sampai $2400 \mathrm{~g}$ dengan rerata berat badan lahir pada kelompok ASI $1809 \mathrm{~g}$, kelompok predominan ASI 1961 g, kelompok predominan SF 2016 g dan SF 2037 g. Rerata panjang badan lahir kelompok ASI $36 \mathrm{~cm}$, kelompok predominan ASI $43 \mathrm{~cm}$, kelompok predominan SF $42 \mathrm{~cm}$ dan SF $40 \mathrm{~cm}$. Status pertumbuhan janin yang sesuai masa kehamilan (SMK) sebanyak 21 (87,5\%) dan kecil masa kehamilan (KMK) sebanyak 3 $(12,5 \%)$. Cara kelahiran sectio caesaria sebanyak $18(75 \%)$ dan kelahiran spontan 6 (25\%).

Kadar Interleukin-4 Feses dan Interleukin 8 Feses

Hasil penelitian mendapatkan kadar IL4 tertinggi pada kelompok ASI 734,55 ng/L, diikuti kelompok predominan ASI 628,12 $\mathrm{ng} / \mathrm{L}$, kelompok predominan susu formula $546,81 \mathrm{ng} / \mathrm{L}$, dan terendah kelompok susu formula 513,83 $\mathrm{ng} / \mathrm{L}$ (Tabel 2). Namun, kadar IL-8 feses didapatkan paling rendah terdapat pada kelompok ASI dengan ratarata 92,59 $\mathrm{ng} / \mathrm{L}$ dan paling tinggi pada perlakuan susu formula dengan rata-rata 276,17 ng/L (Tabel 3).

Hasil uji Kruskal Wallis pada IL-4 feses (Tabel. 2) diketahui bahwa nilai $p=0,007<$ 0,05 . Hal ini menunjukkan ada perbedaan kadar IL-4 yang signifikan pada keempat kelompok. Hasil uji Kruskal Wallis IL-8 feses (Tabel 3) diketahui bahwa nilai $p=0,014$ $<0,05$. Hal ini berarti ada perbedaan yang signifikan kadar IL-8 feses pada keempat kelompok nutrisi. 
Tabel 1. Karakteristik subjek penelitian.

\begin{tabular}{ll}
\hline Karakteristik & Nilai \\
\hline Jenis kelamin, & $\mathrm{n}(\%)$ \\
\hline Laki-laki & $15(62,5)$ \\
Perempuan & $9(37,5)$ \\
\hline Masa kehamilan & $\mathrm{n}(\%)$ \\
\hline Sesuai masa kehamilan & $21(87,5)$ \\
Kecil masa kehamilan & $3(12,5)$ \\
\hline Cara lahir & $\mathrm{n}(\%)$ \\
\hline Spontan & $6(25)$ \\
SCTP & $18(75)$ \\
\hline Usia & median (min-max) \\
\hline Usia kehamilan (minggu) & $7,5(6-18)$ \\
\hline Berat lahir (g) & $33(30-36)$ \\
\hline ASI & $1809,67(1670-1924)$ \\
Susu formula & $2037,67(1614-2372)$ \\
Predominan susu formula & $2016,67(1550-2200)$ \\
Predominan ASI & $1961,67(1530-2400)$ \\
\hline Panjang lahir (cm) & median (min-maks) \\
\hline ASI & $36,83(31-40)$ \\
Susu formula & $42(35-46)$ \\
Predominan susu formula & $40,33(34-44)$ \\
Predominan ASI & $43,5(38-48)$ \\
\hline
\end{tabular}

Tabel 2. Kadar dan hasil uji Kruskal Wallis IL-4 feses.

\begin{tabular}{lccc}
\hline Kelompok & Rata-rata IL-4 (ng/L) & SD & Nilai p \\
\hline ASI & 734,55 & 123,134 & 0,007 \\
\cline { 1 - 3 } SF & 513,83 & 80,544 & \\
\cline { 1 - 3 } Predominan SF & 546,81 & 67,954 & \\
\cline { 1 - 3 } Predominan ASI & 628,12 & 62,226 & \\
\hline
\end{tabular}

Keteranagn: $p<0,05$ signifikan

Tabel 3. Kadar dan hasil uji Kruskal Wallis IL-8 feses.

\begin{tabular}{llcl}
\hline Kelompok & Rata-rata IL8 $(\mathrm{ng} / \mathrm{L})$ & SD & Nilai p \\
\hline ASI & 92,5952 & 21,40316 & 0,014 \\
\cline { 1 - 3 } SF & 276,1667 & 181,88226 & \\
\cline { 1 - 3 } Predominan SF & 189,0238 & 53,04343 & \\
\cline { 1 - 3 } Predominan ASI & 104,0238 & 75,32876 & \\
\cline { 1 - 2 }
\end{tabular}

Keteranagn: $p<0,05$ signifikan 


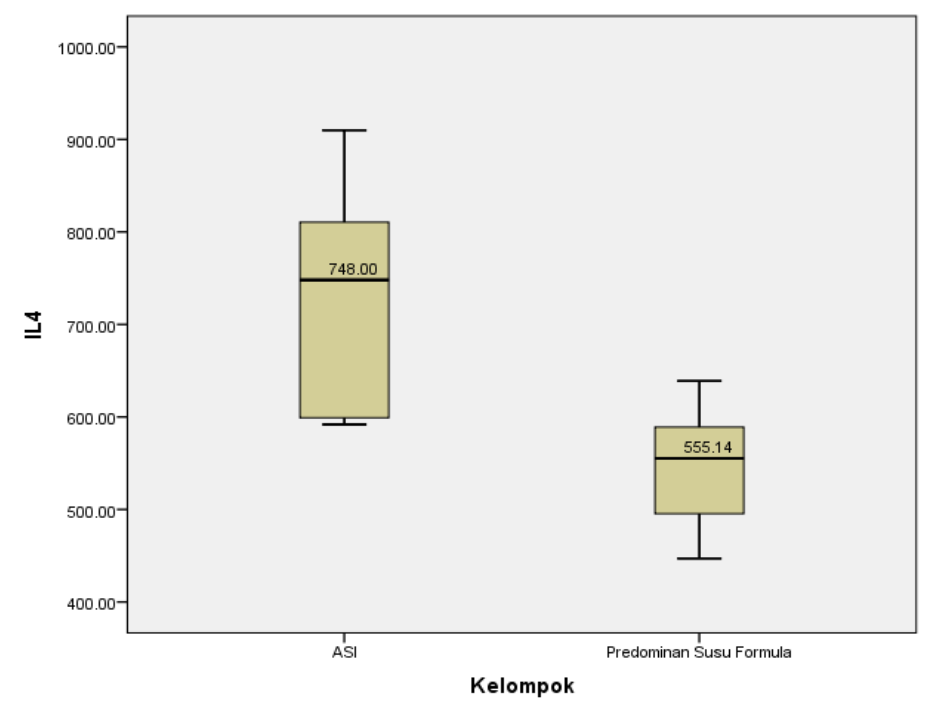

Gambar 1. Kadar interleukin-4 feses pada kelompok ASI dibanding kelompok predominan SF. Keterangan: Gambar boxplot menunjukkan perbandingan antara kadar IL-4 feses kelompok ASI dengan kelompok SF yang berbeda signifikan dengan nilai $p=0,010(p<0,05)$.

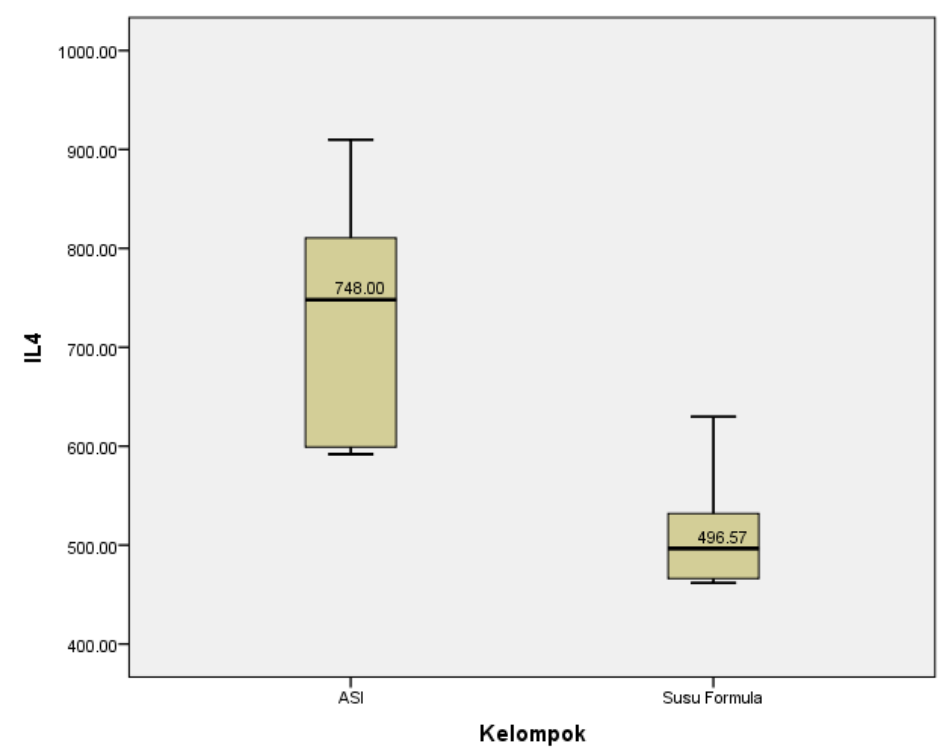

Gambar 2. Kadar interleukin-4 feses pada kelompok ASI dibanding kelompok SF.

Keterangan: Gambar boxplot menunjukkan perbandingan antara kadar IL-4 feses kelompok ASI dengan kelompok predominan $S F$, yang berbeda signifikan $p=0,010(p<0,05)$. 


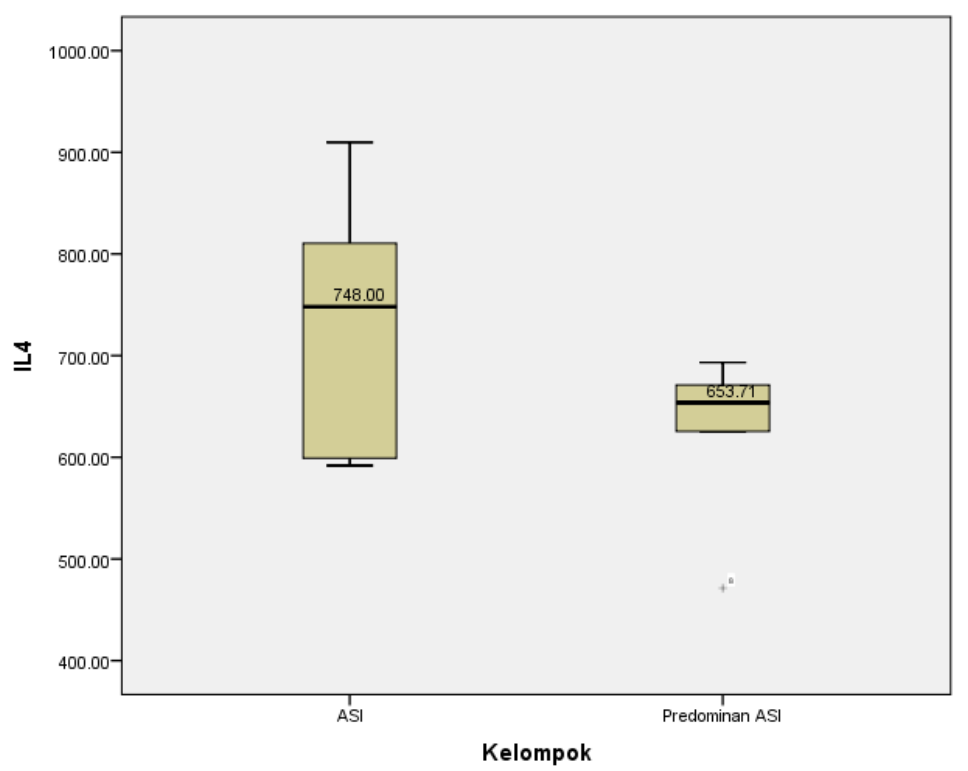

Gambar 3. Kadar interleukin-4 feses pada kelompok ASI dibanding predominan ASI.

Keterangan: Gambar boxplot menunjukkan perbandingan antara kadar IL-4 feses kelompok ASI dengan kelompok predominan ASI, yang menunjukkan tidak ada perbedaan yang signifikan $p=0,2(p$ $>0,05)$.

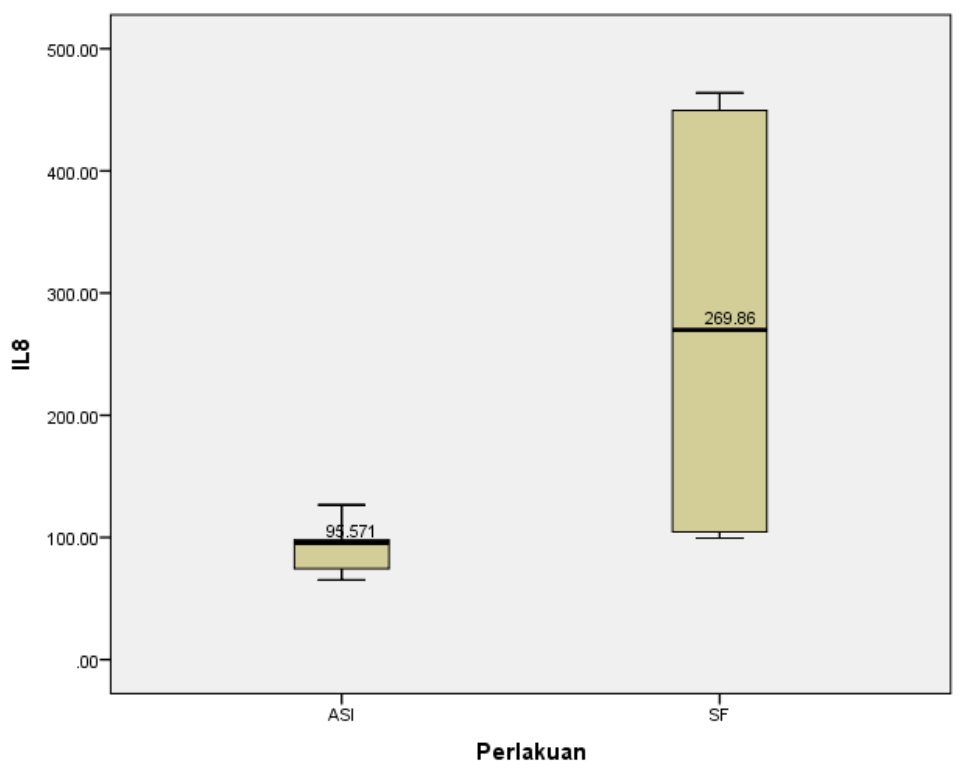

Gambar 4. Kadar interleukin-8 feses pada kelompok ASI dibanding kelompok SF.

Keterangan: Gambar boxplot menunjukkan perbandingan antara kadar IL-8 feses kelompok ASI dengan kelompok SF, yang menunjukkan ada perbedaan yang signifikan $p=0,010(p<0,05)$. 


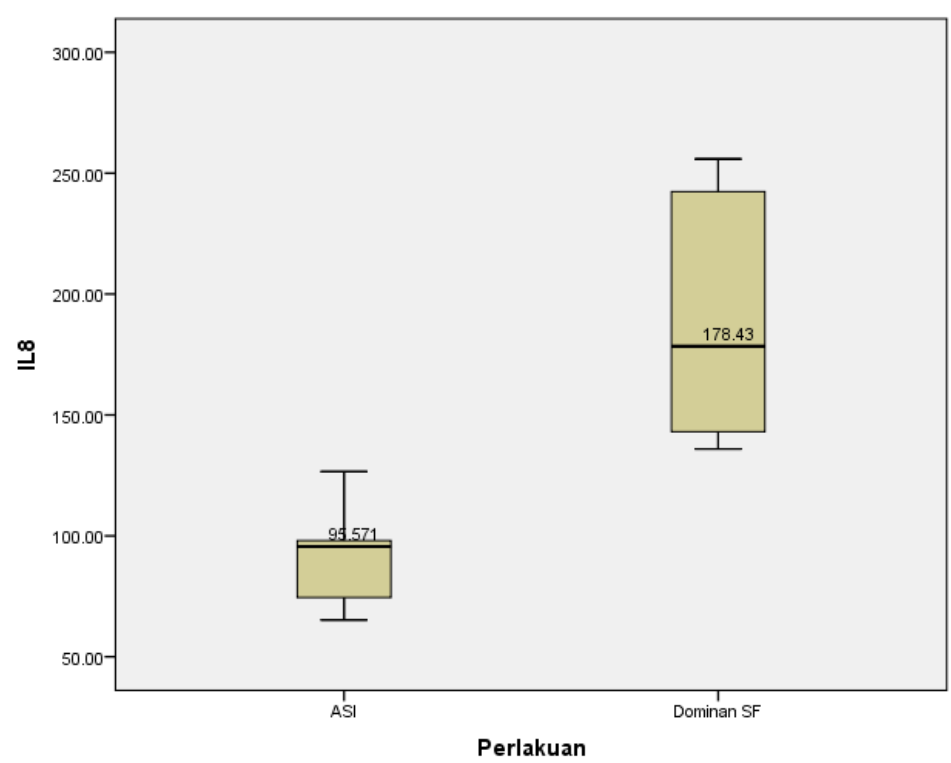

Gambar 5. Kadar interleukin-8 feses pada kelompok ASI dibanding Predominan SF.

Keterangan: Gambar boxplot menunjukkan perbandingan antara kadar IL-8 feses kelompok ASI dengan kelompok predominan SF, yang menunjukkan ada perbedaan yang signifikan $p=0,04(p<$ $0,05)$.

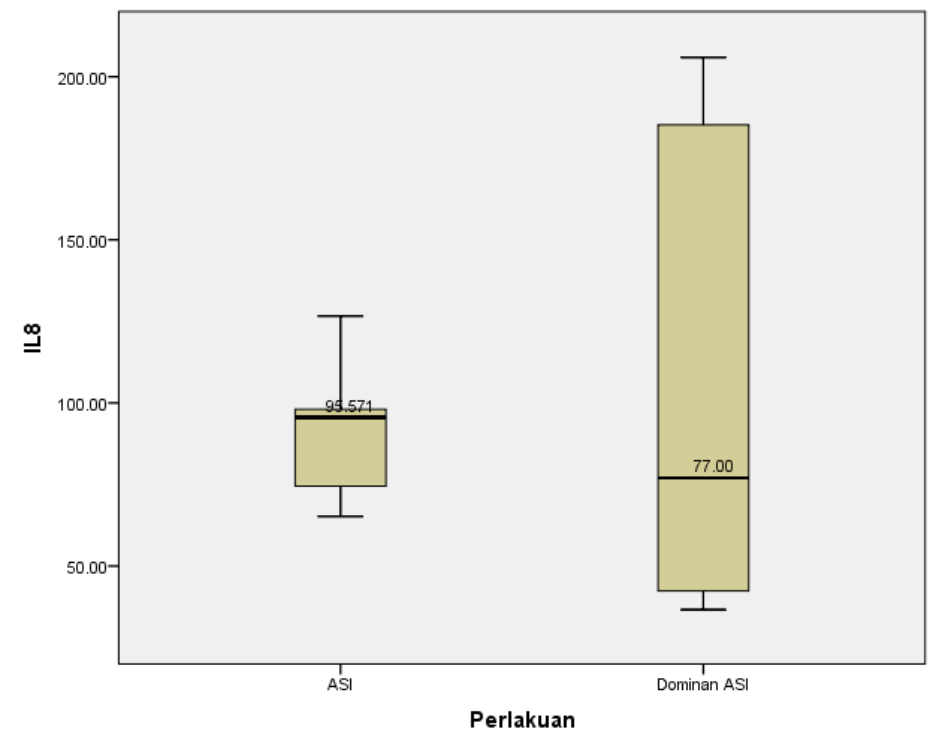

Gambar 6. Kadar interleukin-8 feses pada kelompok ASI dibanding Predominan ASI.

Keterangan: Gambar boxplot menunjukkan perbandingan antara kadar IL-8 feses kelompok ASI dengan kelompok SF, yang menunjukkan tidak ada perbedaan yang signifikan $p=0,87(p>0,05)$.

\section{Pembahasan}

Jenis kelamin responden pada penelitian ini meliputi bayi laki-laki sebanyak $15(62 \%)$ pasien dan bayi perempuan sebanyak 9 (38\%) pasien. Data ini sama dengan penelitian yang menunjukkan bahwa prevalensi terjadinya kelahiran prematur lebih sering pada laki-laki dibanding perempuan dengan persentase sekitar 55$60 \%$ dan umur kehamilan sekitar $30-34$ minggu. ${ }^{9}$

Persentase cara kelahiran pervaginam dan sectio caesaria masing-masing pada kedua kelompok yaitu $75 \%$ dan $25 \%$. Beberapa sumber menyebutkan keputusan 
untuk menentukan sectio caesaria didasarkan pada kondisi darurat yang mengancam kelangsungan hidup ibu dan bayi, misal pada kondisi ibu dengan penyakit hipertensi, adanya perdarahan, dan gawat janin. ${ }^{10}$

Penelitian ini mendapatkan data masa kehamilan yang sesuai masa kehamilan (SMK) sebanyak $21(87,5 \%)$, dan kecil masa kehamilan (KMK) sebanyak 3 (12,5\%). Hal ini seperti penelitian di Taiwan yang menununjukkan prevalensi terjadinya prematur dengan SMK sekitar 70\% dibandingkan dengan KMK yaitu sebesar $30 \%$. Penelitian lain juga menyebutkan angkan kejadian KMK bervariasi antara 10$40 \%$ di berbagai negara. ${ }^{11}$

Selain itu, didapatkan usia kehamilan terendah antara 30 minggu sampai 36 minggu dengan rerata sekitar 33 minggu. Hal ini sesuai dengan penelitian Loftin dkk. yang menunjukkan bahwa kelahiran prematur terbanyak pada usia kehamilan lebih dari 33 minggu. ${ }^{12}$

Pada bayi prematur sering dijumpai adanya inflamasi saluran cerna yang merupakan tanda awal dari nekrosis intestinal yang menjadi salah satu penyebab kegawatan gastrointestinal pada neonatus. Patogenesis inflamasi saluran cerna disebabkan oleh banyak faktor termasuk imaturitas saluran cerna, dan perubahan mikrobiota serta pengaruh dari asupan. Imaturitas saluran cerna membawa dampak lemahnya barrier epitel saluran cerna, dan sistem imun yang tidak berkembang, serta perubahan pada perkembangan vaskular dan tonus saluran cerna. Pada saat pertahanan epitel lemah dan sistem imun yang belum berkembang, dan ketika terpapar dengan mikrobiota luminal yang telah berubah karena pemberian susu formula dan paparan antibiotika, maka akan mengarah pada inflamasi saluran cerna. ${ }^{13}$

Insiden inflamasi saluran cerna pada bayi yang mendapat ASI lebih rendah dibandingkan dengan bayi yang mendapat susu formula. Sebuah penelitian yang membandingkan antara bayi yang mendapat ASI dengan yang mendapat susu formula, diketahui risiko inflamasi saluran cerna meningkat 6-10 kali pada bayi yang mendapat susu formula dan meningkat menjadi 3 kali pada yang campuran. Hasil penelitian ini menunjukkan bahwa ASI akan menurunkan risiko kejadian inflamasi saluran cerna utamanya pada kondisi prematur.

Air susu ibu mengandung beberapa faktor bioaktif protektif seperti immunoglobulin, enzim, laktoferin, faktor pertumbuhan, oligosakarida, dan asam lemak yang dapat bermanfaat pada usus. Selain itu ASI juga menstimulasi kolonisasi organisme yang menguntungkan seperti Bifidobacterium dan Lactobacillus, sehingga akan memberikan keuntungan yaitu mengurangi risiko terjadinya inflamasi saluran cerna. ${ }^{14,15}$ Air susu ibu merupakan strategi yang paling efektif dalam melindungi bayi terhadap inflamasi saluran cerna. Menurut penelitian Good dkk. (2015) air susu ibu mencegah inflamasi saluran cerna melalui inhibisi TLR4 (toll like receptor) di dalam epitel usus, melalui aktivasi EGF. Ekspresi TLR4 yang rendah dalam epitel usus,menunjukkan efek proteksi ASI. Efek proteksi ini melalui inhibisi apoptosis enterosit dan perbaikan proliferasi enterosit. ${ }^{16}$

Saluran cerna dipengaruhi proses regulasi sitokin proinflamasi dan antiflamasi agar terjadi homeostasis tubuh, salah satu sitokin antiiflamasi adalah IL-4. Pada kejadian enterokolitis nekrotikan (EKN) kadar IL-4 menunjukkan kadar yang rendah dibandingkan pada kontrol. Interleukin-4 adalah sitokin kontra regulasi yang sering didefinisikan sebagai sebuah modulator kekebalan karena dapat menghambat pelepasan sitokin proinflamasi.3,5,17

Sebuah studi tentang kaitan colitis ulseratif dengan ekspresi sitokin pada 
mukosa dengan cara biopsi, berbagai macam sitokin diperiksa salah satunya IL-4, didapatkan hasil kadar yang rendah secara signifikan dibandingkan kontrol $(p=<$ $0,005) \cdot{ }^{18}$ Penelitian lain yang dilakukan pada pasien diare anak di negara berkembang mencari hubungan antara kondisi diare dengan respons imun. Sampel yang diperiksa adalah feses dan dievaluasi kadar TNF alpha, monocyte chemoactractan, IL-4, IL-5, IL-6, IL-8, IL-10 dan interferon-y. Diidapatkan hasil peningkatan kadar IL-4, IL5 dan interferon-y feses pada anak yang dihubungkan dengan durasi infeksi. ${ }^{19}$ Penelitian tersebut membuktikan bahwa IL-4 mempunyai peran pada kondisi inflamasi saluran cerna.

Pada penelitian ini ditemukan bahwa konsentrasi IL-8 feses paling rendah pada kelompok ASI, diikuti kelompok predominan ASI, predominan SF dan tertinggi SF dengan perbedaan yang signifikan secara statistik ( $p$ $=0,014)$. Rendahnya kadar IL-8 feses pada saluran cerna subjek yang tergambar pada rendahnya kadarnya di feses menunjukkan proses inflamasi yang rendah pada kelompok ASI. Namun, pada kelompok yang mendapat susu formula kadarnya lebih tinggi, menunjukkan terdapat peningkatan proses inflamasi pada kelompok ini. Dapat disimpulkan bahwa nutrisi dengan ASI akan menurunkan risiko kejadian infamasi saluran cerna. Interleukin-8 adalah sitokin proinflamasi, berbagai jenis sel dapat memproduksi IL-8, diantaranya monosit, makrofag, dan sel endotel dan astrosit. Beberapa penelitian menyebutkan bahwa IL8 berkaitan dengan kasus EKN dan semakin tinggi kadar IL-8 maka derajat EKN semakin berat. Hal tersebut menunjukkan bahwa semakin berat proses inflamasi pada saluran cerna maka kadar IL-8 juga semakin tinggi. ${ }^{20}$ Sebuah penelitian menunjukkan kadar IL-8 feses meningkat pada pasien dengan infeksi saluran pencernaan karena clostridium dengan gejala diare. ${ }^{21}$ Penelitian lain juga menunjukkan peningkatan kadar IL-8 pada anak dengan keluhan diare karena rotavirus. ${ }^{6,7}$

\section{Kesimpulan}

Ada perbedaan kadar IL-4 feses dan IL-8 feses antara kelompok bayi prematur yang mendapatkan ASI, predominan ASI, predominan SF dan SF. Kadar interleukin-4 feses kelompok ASI lebih tinggi dibandingkan kelompok SF dan kelompok predominan SF dan kadar IL-8 feses kelompok ASI lebih rendah dibandingkan kelompok SF dan predominan SF, serta tidak ada perbedaan kelompok ASI dibanding predominan ASI baik pada IL-4 feses maupun IL-8 feses.

\section{Saran}

Dibutuhkan penelitian lanjutan secara komprehensif yang mengukur kadar IL-4 dan IL-8 feses pada kondisi neonatus prematur yang lebih spesifik dan diperlukan penelitian lanjutan mengenai kadar biomarker non invasif yang lain yang kaitannya dengan kondisi inflamasi saluran cerna pada neonatus.

\section{Daftar Pustaka}

1. Juhl SM. Necrotizing Enterocolitis Classification and Two Initial Steps Towards Prevention. Danish Med Journal. 2017; 64(6):53-62.

2. Frost BL, Jilling $T$, Lapin $B$, Maheshwari A, Caplan MS. Maternal Breast Milk Transforming Growth Factor Beta and Feeding Intolerance in Preterm Infants. Journal Pediatr Res. 2014; 76(4):386393.

3. Maheshwari A, Schelonka RL, Dimmitt RA, Carlo WA., Munoz-Hernandez B, Das A, Mcdonald SA., Thorsen P, 
Skogstrand K, Hougaard DM. Cytokines

4. in Extremely Low Birth Weight Infants. Pediatric Research. 2014; 76:100-108.

5. Corebima B. Kadar Human Defensin dalam Tinja dan Pola Mikrobiota Saluran Cerna pada Neonatus Kurang Bulan yang Mendapat ASI, Susu Formula, dan Kombinasi. Tesis. Jakarta: Fakultas Kedokteran Universitas Indonesia. 2017.

6. Müzes G, Molnár B, Tulassay Z, Sipos F. Changes of the Cytokine Profile in Inflammatory Bowel Diseases. World Journal Gastroenterol. 2012; 8(41): 58485861.

7. Feghaly RE, Stauber JL, Phillip MS, David BH. Intestinal Inflammatory Biomarkers and Outcome in Pediatric Clostridium difficile Infections. Journal Pediatr. 2013; 163(6):1697-1704.

8. Chen SM. The Significance of Serum and Fecal Levels of Interleukin-6 and Interleukin-8 in Hospitalized Children with Acute Rotavirus and Norovirus Gastroenteritis. Pediatrics and Neonatology. 2014; 55:120-126.

9. Dahlan S. Statistik untuk Kedokteran dan Kesehatan. Edisi Ke-5. Jakarta: Salemba Medika. 2011.

10. Blencowe H, Simon C, Doris C, Mikkel O, Lale S , Ann-Beth M , Mary K. Born Too Soon: The Global Epidemiology of 15 Million Preterm Births. Reproductive Health. 2013; 10(Suppl 1): S2. doi: 10.1186/1742-475510-S1-S2

11. Hondegla AD, Aboubakar A, Egloh A. Indications and Prognosis of Fetal Extractions by Caesarean Section Before 34 Weeks of Amenorrhea in Black African Context. Obstet Gynecol Int J. 2016; 4(2): 00100.

12. Tsai LY, Chen YL, Tsou KI, Mu SC. The Impact of Small for Gestational Age on Neonatal Outcome among Very Low Birth Weight Infants. Pediatr Neonatol. 2015; 56(2):101-7.
Associated with Necrotizing Enterocolitis 13. Loftin RW, Habli M, Snyder CC, Clint M, Lewis D, Emily A. De Franco DO. Late Preterm Birth. Rev Obstet Gynecol. 2010; 3(1):10-19.

14. Ahle M, Drott $P$, Andersson $R$. Epidemiology and Trends of Necrotizing Enterocolitis in Sweden. Pediatrics. 2013; 132:1-11.

15. Neu J, Walker WA. Necrotizing Enterocolitis. New England Journal of Medicine. 2011; 364:255-264.

16. Chu A, Hageman J, Caplan M. Necrotizing Enterocolitis Predictive Markers and Preventive Strategies. NeoReviews. 2013; 14:113-120.

17. Good M, Sodhi CP, and Hackam DJ. Evidence-Based Feeding Strategies Before and After the Development of Necrotizing Enterocolitis. Expert Review of Clinical Immunology. 2014; 10: 875884.

18. Benkoe TM. Serum Levels of Interleukin8 and Gut-Associated Biomarkers in Diagnosing Necrotizing Enterocolitis in Preterm Infants. J Pediatr Surg. 2014; 49(10):1446-51.

19. Pearl D, Shah K, Whittaker M, Smith H, Brown J, Shute J. Cytokine Mucosal Expression in Ulcerative Colitis, The Relationship between Cytokine Release and Disease Activity. Journal of Crohn and Colitis. 2013; 7:481-489.

20. Long K, Rosado J, Santos J, Haas M, Abdullah M, Dupont $\mathrm{H}$, Nanthakumar N, Garcia T. Association between Mucosal Innate and Adaptive Immune Response and Resolution of Diarrheal Patogen Infection. Infection and Immunity. 2010; 78(3):1221-1228.

21. Hunter $C$, Plaen I. Inflammatory Signaling in NEC: Role of NF- KB, Cytokines and Other Inflammatory Mediators. Pathophysiology. 2014; 21:55-65. 